\title{
Олександра ВАСИЛЬЧИШИН
}

доктор економічних наук, профресор, Західноукраїнський національний університет, Тернопіль, Україна, volexandra@gmail.com ORCID ID: 0000-0002-9948-5532

\section{ФІНАНСОВІ ЗАОЧИНИ У ФІСКААЫНІЙ СФЕРІ ЯК ЗАГРОЗА ЕКОНОМІЧНІЙ БЕЗПЕЦІ УКРӒ̈НИ}

Вступ. На сьогодні в Україні посилюються такі криміногенні явища, як тінізація та монополізація економіки, легалізація (відмивання) майна, одержаного злочинним шляхом, тощо. Останні зміни у законодавстві та перспективи рефрормування фріскальних й правоохоронних інституцій потребують перманентного дослідження стану попередження, виявлення та розслідування фрінансових злочинів у фріскальній сфрері. У цьому контексті важливим завданням є створення єдиної інституції з відповідними функціями, правами й повноваженнями.

Мета - виокремити реальні та можливі ризики щодо формування дієвих оптимальних напрямів забезпечення економічної безпеки України на основі аналізу особливостей здійснення процесів запобігання, виявлення, припинення, розслідування та розкриття фрінансових злочинів у фріскальній ссрері.

Meтоди. У дослідженні стану попередження, виявлення та розслідування фрінансових злочинів у фіскальній сфрері використано низку загальнонаукових і спеціальних методів дослідження, зокрема: аналіз, синтез, індукцію, дедукцію, абстрактно-логічний метод та метод узагальнення.

Результати. Обгрунтовано необхідність створення єдиної інституції щодо попередження, виявлення, розслідування фрінансових злочинів, зокрема й у фріскальній сфрері. На основі статистичних даних державних органів визначено вісім схем уникнення оподаткування в Україні, які призводять до загальних втрат бюджету. Проаналізовано структуру предикатних злочинів в обвинувальних вироках судів протягом останніх років та окреслено основні види предикатних злочинів у фріскальній сфрері. Доведено, що в українській практиці кількість кримінальних проваджень за ухилення від сплати податків, доведених до постановлення вироку і притягнення до відповідальності, різко зменшується, що свідчить про: фрактичну безкарність вчинення злочинів у фіскальній сфері; бездіяльність або перевищення повноважень, тобто неналежне розслідування особами, що здійснюють розслідування цих злочинів, наявність корупційної складової у процесі досудового розслідування; некомпетентність слідчих (детективів), що здійснюють розслідування злочинів у фріскальній сфрері, а також недостатній рівень знань у фріскальній сорері прокурорів як процесуальних керівників. Це дало можливість аргументувати доцільність створення Бюро економічної безпеки. Відповідно до аналізу

(с) Олександра Богданівна Васильчишин, 2021 
диспозицій статей Особливої частини Кримінального кодексу України визначено дванадиять статей, які слід відносити до податкових злочинів.

Перспективи. Подальші наукові дослідження доцільно спрямувати на пошук оптимального підходу до вирішення питання підслідності фрінансових злочинів у фріскальній сфрері, а також на забезпечення належного рівня економічної безпеки України.

Ключові слова: фрінансовий злочин, фріскальна сфрера, фрінансове розслідування, легалізація (відмивання) майна, Бюро економічної безпеки.

Рис.: 3, бібл.: 19.

\section{Александра ВАСИЛЬчИШИН}

доктор экономических наук, професссор, Западноукраинский национальный университет, Тернополь, Украина

\section{ФИНАНСОВЫЕ ПРЕСТУПАЕНИЯ В ФИСКААЬНОЙ СФЕРЕ КАК УГРОЗА ЭКОНОМИЧЕСКОЙ БЕЗОПАСНОСТИ УКРАИНЫ}

Введение. На сегодняшний день в Украине усиливаются такие криминогенные явления, как тенизация и монополизация экономики, легализация (отмывание) имущества, полученного преступным путем, и тому подобное. Последние изменения в законодательстве и перспективы реформирования фискальных и правоохранительных институтов требуют перманентного исследования состояния предупреждения, выявления и расследования финансовых преступлений в фискальной сфере. В этом контексте важной задачей является создание единого института с соответствующими функциями, правами и полномочиями.

Цель - определить реальные и возможные риски формирования действенных оптимальных направлений обеспечения экономической безопасности Украины на основе анализа особенностей осуществления процессов предупреждения, выявления, пресечения, расследования и раскрытия фринансовых преступлений в фискальной сфере.

Методы. В исследовании состояния предупреждения, выявления и расследования финансовых преступлений в фрискальной сфере использован ряд общенаучных и специальных методов исследования, в частности: анализ, синтез, индукция, дедукция, абстрактно-логический метод и метод обобщения.

Результаты. Обоснована необходимость создания единого института по предупреждению, выявлению, расследованию фринансовых преступлений, в том числе и в фискальной сфрере. На основе статистических данных государственных органов определены восемь схем ухода от налогообложения в Украине, которые приводят к общим потерям бюджета. Проанализирована структура основных правонарушений в обвинительных приговорах судов в последние годы и очерчено основные виды основных правонарушений в фискальной сфрере. Доказано, что в украинской практике количество уголовных производств за уклонение от уплаты налогов, доведенных до вынесения приговора и привлечения к ответственности, резко уменьшается, что свидетельствует о: фрактической безнаказанности совершения преступлений в фрискальной сфере; бездействии или превышении полномочий, то есть о ненадлежащем расследовании лицами, осуществляющими расследование этих преступлений, наличии коррупционной составляющей в процессе досудебного расследования; некомпетентности следовате- 
лей (детективов), осуществляющих расследование преступлений в фрискальной сфрере, а также недостаточном уровне знаний в фискальной сфере прокуроров как процессуальных руководителей. Это дало возможность аргументировать целесообразность создания Бюро экономической безопасности. Исходя из анализа диспозиций статей Особенной части Уголовного кодекса Украины, определено двенадцать статей, которые следует относить к налоговым преступлениям.

Перспективы. Дальнейшие научные исследования целесообразно направить на поиск оптимального подхода к решению вопроса подследственности финансовых преступлений в фискальной сфрере, а также на обеспечение надлежащего уровня экономической безопасности Украины.

Ключевые слова: фринансовое преступление, фрискальная сфрера, фринансовое расследование, легализация (отмывание) имущества, Бюро экономической безопасности.

\section{Oleksandra VASYLCHYSHYN}

Dr. Sc. (Economics), Prof., West Ukrainian National University, Ternopil, Ukraine, volexandra@gmail.com ORCID ID: 0000-0002-9948-5532

\section{FINANCIAL CRIMES IN THE FISCAL SPHERE AS A THREAT TO THE ECO- NOMIC SECURITY OF UKRAINE}

Introduction. Such criminogenic phenomena as shadowing and monopolization of the economy, legalization (laundering) of criminally obtained property are intensifying today in Ukraine. Recent changes in legislation and prospects for reforming fiscal and law enforcement institutions require a permanent study of the state of prevention, detection and investigation of financial crimes in the fiscal sphere. In this context, an important task is to create a single institution with appropriate functions, rights and powers.

The purpose of the article is to identify real and possible risks for the formation of effective optimal directions for ensuring the economic security of Ukraine based on the analysis of the peculiarities of the processes of prevention, detection, termination, investigation and detection of financial crimes in the fiscal sphere.

Methods. A number of general and special research methods were used in the study of the prevention, detection and investigation of financial crimes in the fiscal sphere, in particular: analysis, synthesis, induction, deduction, abstract-logical method and generalization method.

Results. The necessity of creating a single institution for the prevention, detection and investigation of financial crimes, including in the fiscal sphere, is substantiated. Based on government statistics, the eight most popular tax avoidance schemes in Ukraine have been identified, leading to total budget losses. The structure of predicate crimes in court convictions in recent years is analyzed, and the main types of predicate crimes in the fiscal sphere are outlined. It is proved that in Ukrainian practice the number of criminal proceedings for tax evasion, brought to sentencing and prosecution decreases sharply, which indicates: the actual impunity for committing crimes in the fiscal sphere; inaction or excess of authority, improper investigation by the persons investigating these crimes, the presence of a corruption component in the pre-trial investigation; incompetence of investigators (detectives) investigating crimes in the fiscal sphere, as well as insufficient level of knowledge in the fiscal sphere of prosecutors as procedural managers. This made it possible to argue the feasibility of creating an economic security bureau. 
Based on the analysis of the dispositions of the articles of the Special Part of the Criminal Code of Ukraine, twelve articles have been identified that should be classified as tax crimes.

Perspectives. Further research should focus on finding the best approach to addressing the issue of financial crime in the fiscal sphere, as well as to ensure the appropriate level of economic security in Ukraine.

Keywords: financial crime, fiscal sphere, financial investigation, legalization (laundering) of property, Bureau of Economic Security.

JEL Classification: G28, H39, K34.

Постановка проблеми. На сьогодні в Україні посилюються такі криміногенні явища, як тінізація та монополізація економіки, легалізація (відмивання) майна, одержаного злочинним шляхом, тощо. Звідси формується загрозлива ситуація у економічній сфрері країни, зокрема у фріскальній, де останніми роками збільшилася кількість протиправних діянь, які призводять до ненадходження до бюджету країни значних коштів та їх привласнення злочинними елементами, що загалом створює загрозу й економічній безпеці України. За таких реалій в Україні залишається відкритим питання діяльності податкової міліції, а саме реформування ії функцій, повноважень і підслідності до Бюро економічної безпеки України [1]. Як наслідок такого стану очікування реформи $€$ або перевищення повноважень посадових осіб фріскальних інституцій, або їх бездіяльність, або перекручування норм податкового, кримінального, адміністративного права у процесі розслідування фінансових злочинів, що призводить до хаосу у фіскальній сфрері та формує зростання недовіри до Державної фіскальної служби України (ДФС) та й до держави загалом. Тому, враховуючи вищенаведене, а також зростання діджиталізації у фрінансовій сфрері послуг, що фрормує нові схем ухилення від оподаткування, високу латентність фрінансових злочинів, що зумовлено відсутністю "прямих" потерпілих (адже вони завдають шкоди безпосередньо інтересам держави), питання фрінансових злочинів у фріскальній сфрері потребує наукового дослідження з урахування сучасних особливостей економічних відносин, змін у законодавстві та перспектив реформування фріскальних й правоохоронних інституцій, що здійснюють розслідування фрінансових злочинів.

Аналіз останніх досліджень і публікацій. Питання попередження, виявлення, розкриття та розслідування податкових злочинів, ефективність діяльності податкової міліції досліджували такі науковці, як: П. Цимбал [2], В. Хоменко [3]. Проблеми здійснення фінансових розслідувань у сфрері протидії легалізації злочинних доходів в Україні висвітлювали у своїх працях С. Чернявський, О. Користін, В. Некрасов, Л. Герасименко, О. Тихонова, А. Чубенко, В. Мельник [4], Д. Долбнєва [5]. Формування фріскального простору України в умовах глобалізаційних дисбалансів досліджували професори А. Крисоватий, О. Десятнюк, О. Сидорович [6]. Питання створення в Україні інституції попередження, виявлення та розслідування фінансових злочинів для забезпечення економічної безпеки України проаналізував Г. Катамадзе [7]. Проте зміни у законодавстві та перспективи реформування фріскальних і правоохоронних інституцій потребують перманентного дослідження стану попередження, виявлення та розслідування фінансових злочинів у фріскальній сфері задля окреслення ризиків 
і формування оптимальних напрямків забезпечення економічної безпеки України.

Мета статті полягає у виокремленні реальних та можливих ризиків щодо формування дієвих оптимальних напрямків забезпечення економічної безпеки України на основі аналізу особливостей здійснення процесів запобігання, виявлення, припинення, розслідування та розкриття фрінансових злочинів у фіскальній сфері.

Виклад основного матеріалу дослідження. За розрахунками Мінекономіки, рівень тіньової економіки у січні-березні 2020 р. становив $31 \%$ від обсягу офріційного ВВП. Збереження тенденції до зниження тіньової економіки відбулося, незважаючи на поширення негативних наслідків пандемії COVID19 і зниження рівня реального ВВП на 1,3\%, за підсумком I кварталу 2020 р. до відповідного кварталу 2019 р. [8]. Разом з тим, аналізуючи досвід попередніх криз, очікуваним було збільшення рівня тіньової економіки, адже в умовах значної невизначеності бізнес прагне зменшити ризики втрати ресурсів. Звідси значно зросли збитки в економіці держави, оскільки зафіксовано ендогенне й екзогенне зменшення інвестиційної та ділової активності.

Особливості у висновках дослідження тінізації економіки України експертами IHституту соціально-економічної трансформації полягають у тому, що, на відміну від інших країн, структура тіньової економіки в Україні не сконцентрована у сорері незареєстрованого підприємництва або дрібних послуг та торгівлі, а наймасштабніші інструменти ухилення від податків застосовують в Україні саме великі підприємства, які домінують у своїх галузях і зазвичай мають “політичний захист та імунітет” від контролю фріскальних і правоохоронних органів.

На основі статистичних даних державних органів можна виокремити вісім найпопулярніших схем уникнення оподаткування в Україні, які призводять до загальних втрат бюджету на більш ніж 180 млрд грн:

- офшорні схеми (приблизні обсяги - 260-320 млрд грн на рік або 5065 млрд грн втрат бюджету на рік);

- "сірий імпорт", контрабанда (приблизні обсяги - 80-230 млрд грн на рік або 25-70 млрд грн втрат бюджету на рік);

- конвертаційні центри, а саме такі підприємства або група підприємств, фрірм, організацій, які надають послуги 3 відмивання грошей (приблизні обсяги - 40-50 млрд грн на рік або 1215 млрд грн втрат бюджету на рік);

- податкові “скрутки” (нагадаємо, що це зменшення податкового зобов'язання зі сплати ПДВ, нарахованого із продажу бізнесом одного товару, завдяки податковому кредиту, отриманому при купівлі іншого; приблизні обсяги - 5060 млрд грн на рік або 10-12 млрд грн втрат бюджету на рік);

- контрафакти (приблизні обсяги - 5060 млрд грн на рік або 10-12 млрд грн втрат бюджету на рік);

- фрізична особа-підприємець замість найму (приблизні обсяги - 10 млрд грн на рік або 2,5-5 млрд грн втрат бюджету на рік);

- виведення прибутку через псевдопідприємництво фрізосіб (приблизні обсяги - 3-7 млрд грн на рік або 0,7-3 млрд грн втрат бюджету на рік);

- заниження оборотів (приблизні обсяги 18-20 млрд грн на рік або 1-1,5 млрд грн втрат бюджету на рік) [9, с. 33].

Враховуючи диспозиції статей Кримінального кодексу України (КК України), зокрема його особливої частини [10], та склад злочинної діяльності, шкоди, яка спричиняється діянням, до податкових злочинів, як основних, так і додаткових, варто віднести:

- ухилення від сплати податків, зборів, інших обов'язкових платежів (ст. 212 КК України); 
- ухилення від сплати єдиного внеску на загальнообов'язкове державне соціальне страхування та страхових внесків на загальнообов'язкове державне пенсійне страхування (ст. $212^{1}$ КК України);

- незаконне виготовлення, підроблення, використання та збут незаконно виготовлених, одержаних або підроблених марок акцизного збору чи контрольних марок (ст. 216 КК України);

- доведення банку до неплатоспроможності (ст. 2181 КК України);

- доведення до банкрутства (ст. 219 КК України);

- порушення порядку ведення бази даних про вкладників або порядку формування звітності (ст. 2201 КК України);

- фральсифрікацію фрінансових документів і звітності фрінансової організації, приховування неплатоспроможності фрінансової установи або підстав для відкликання (анулювання) ліцензії фрінансової установи (ст. $220^{2}$ КК України);

- шахрайство з фрінансовими ресурсами (ст. 222 КК України);

- легалізація (відмивання) майна, одержаного злочинним шляхом (ст. 209 КК України);

- незаконне виготовлення, зберігання, збут або транспортування з метою збуту підакцизних товарів (ст. 204 КК України);

- контрабанда (ст. 201 КК України);

- підроблення документів, які подають для проведення державної реєстрації юридичної особи та фрізичних осіб-підприємців (ст. $205^{1}$ КК України).

На думку дослідника П.В. Цимбала, з якою ми погоджуємся, одним із основних критеріїв, за яким перераховані злочини віднесені до податкових, є спрямованість діяння проти фіскальної системи та спричинення шкоди у вигляді ненадходження податків, зборів (інших обов'язкових платежів). У більшості випадків злочини, які виокремлені як податкові, характеризуються корисливим спрямуванням; здійснюються під прикриттям легальної підприємницької діяльності; продовжуються протягом значного проміжку часу; спричиняють значну матеріальну шкоду суспільним відносинам; здійснюються фрізичними чи службовими особами суб'єктів підприємницької діяльності [2].

Зауважимо, що термін "фрінансові розслідування” активно застосовують міжнародні організації, підслідністю яких є відстеження операцій із відмиванням коштів, серед яких - FATF, CFATF тощо. У загальному значенні фрінансові розслідування С. Чернявський, О. Користін, А. Чубенко трактують "як збирання, закріплення, усебічний розгляд, вивчення фрінансової звітності та відстеження фрінансових операцій, що спрямовані на виявлення протиправних діянь, пов'язаних з отриманням, використанням або розподілом фрінансових ресурсів, наприклад, порушення податкового законодавства" [4, с. 9-10].

Також погоджуємося із висновком групи науковців на чолі із професором С. Чернявським, що фінансові розслідування $€$ надзвичайно складним видом дослідження. По-перше, їх здійснення потребує багаторічного досвіду роботи з фінансовою сфрерою. По-друге, самостійними зусиллями жодне відомство не в змозі охопити широкий спектр інформації, необхідної для відстеження всіх фрінансових операцій. Потретє, масштабність, різноманітність і мінливість фрінансового сектору зумовлюють ускладнення фінансових розслідувань. До предмета фрінансових розслідувань, як особливого виду аналізу, належить фрінансова складова злочинної діяльності [4, с. 11]. Отже, злочин, який містить фрінансову складову, ми визначаємо як фрінансовий.

Зауважимо, що, згідно із законодавством України, “Державна фріскальна служба України є центральним органом виконав- 
чої влади, який, окрім реалізації державної податкової політики, державної політики у ссрері державної митної справи, державної політики з адміністрування єдиного внеску на загальнообов'язкове державне соціальне страхування (далі - єдиний внесок), здійснює державну політику у сфері боротьби 3 правопорушеннями під час застосування податкового, митного законодавства, а також законодавства з питань сплати єдиного внеску" [11].

Також, згідно з Положенням Кабінету Міністрів України “Про Державну фріскальну службу”, “основними завданнями ДФС $€$ реалізація державної податкової політики та політики у сфері державної митної справи, державної політики у сфрері боротьби з правопорушеннями під час застосування податкового, митного законодавства, здійснення в межах повноважень, передбачених законом, контролю за надходженням до бюджетів та державних цільових фондів податків і зборів, митних та інших платежів, державної політики у сфрері контролю за виробництвом та обігом спирту, алкогольних напоїв і тютюнових виробів, державної політики з адміністрування єдиного внеску, а також боротьби з правопорушеннями під час застосування законодавства з питань сплати єдиного внеску, державної політики у сфері контролю за своєчасністю здійснення розрахунків в іноземній валюті в установлений законом строк, дотриманням порядку проведення готівкових розрахунків за товари (послуги), а також за наявністю ліцензій на провадження видів господарської діяльності, що підлягають ліцензуванню відповідно до закону, торгових патентів" [11].

Отже, досудове розслідування злочинів у податковій сфері за підслідністю на сьогодні належить до повноважень підрозділів ДФС відповідно до прописаних у п. 4 Положення “Про Державну фіскальну службу" [11] завдань, зокрема: провадить, від- повідно до закону, оперативно-розшукову діяльність, досудове розслідування, а також вживає заходів до відшкодування завданих державі збитків; здійснює розшук осіб, які переховуються від слідства та суду за кримінальні правопорушення у сфері оподаткування, митній та бюджетній сферах; вживає заходів для виявлення, аналізу та перевірки фінансових операцій, які можуть бути пов'язані з легалізацією (відмиванням) доходів, одержаних злочинним шляхом, або фрінансуванням тероризму тощо.

Звісно, що в окремих питаннях у ході досудового розслідування фрінансових злочинів у фіскальній сфрері, залежно від особливостей виявленого злочину, ДФС передає розслідування певних злочинів за підслідністю й у Службу безпеки України, й у Національне антикорупційне бюро України, й Національній поліції. Тобто в Україні на сьогодні розслідуванням злочинів, що спрямовані проти інтересів держави у фріскальній сфері та й у суміжних сфрерах, займаються відповідної інституції, що зображені на рис. 1.

Наявність кількох органів, що мають повноваження здійснювати розслідування фрінансових злочинів, створює низку спірних питань, пов'язаних із розмежуванням компетенції, здійсненням взаємодії, визначенням відповідальних осіб, що, як наслідок, спричиняє виникнення конфліктів щодо підслідності. Це призводить до того, що під час судових розглядів виникає питання щодо визнання недопустимими доказів, зібраних із порушенням правил підслідності. I як системність взаємозв'язку цих дій породжує бездіяльність у розслідуванні, провокує закриття проваджень без належного розслідування, а це призводить до негласного “дозволу" вчиняти й надалі такі злочини. Отже, така розпорошеність і необхідність вирішення наслідків цього явища $є$ однією із підстав створення єдиного органу, інституції 


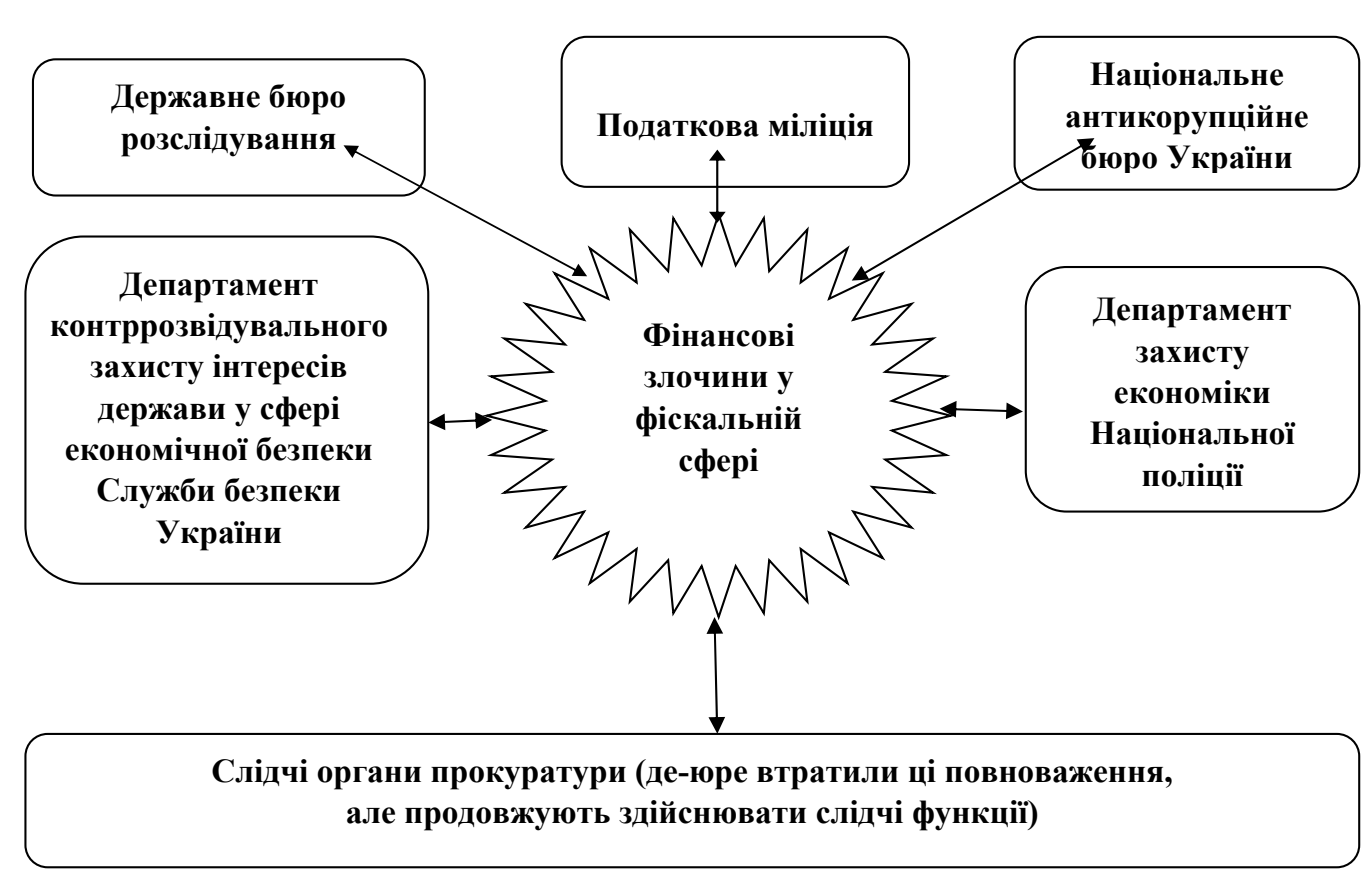

Рис. 1. Інституції, наділені повноваженнями розслідувати злочини, що спрямовані проти інтересів держави у фіскальній сфері, станом на 2020 р.

щодо розслідування економічних злочинів, зокрема й фінансових у фіскальній сфері, як Бюро економічної безпеки України.

Згідно з проєктом Закону України “Про Бюро економічної безпеки” [1], основними завданнями такої інституції мають бути: запобігання, виявлення, припинення, розслідування та розкриття кримінальних правопорушень, віднесених законом до його підслідності; участь у забезпеченні економічної безпеки держави шляхом комплексної протидії кримінальним правопорушенням, які мають суттєвий негативний вплив на національну економіку, сприяють ії̈ тінізації, витоку капіталу та іншим негативним явищам, які уповільнюють темпи економічного зростання та загрожують національним інтересам у сорері економіки; збирання та аналіз інформації щодо економічної злочинності, віднесених законом до підслідності Бюро економічної безпеки України, та визначення способів запобігання їх виникненню в майбутньому".

Повернемось до того, що основними завданнями розслідування фрінансових злочинів є: виявлення загроз або фракторів негативного характеру; визначення розміру збитків, заподіяних економічним злочином; встановлення реальних причин загроз і ризиків. Отже, розслідування фрінансових злочинів можуть бути засобом виявлення предикатних злочинів, які були невідомі раніше та дають змогу виявити інших причетних осіб чи угрупувань.

У Конвенції про відмивання коштів, пошук, арешт та конфріскацію доходів, одержаних злочинним шляхом, предикатний злочин розглядається як діяння, що спрямоване на отримання незаконних доходів, які становлять предмет такого злочину, як “відмивання" [12, с. 185]. Тобто, предикативні злочини - це суспільно небезпечне 
протиправне діяння, що передувало легалізації (відмиванню) доходів, одержаних злочинним шляхом в обхід оподаткуванню.

Щодо ситуації в Україні, то протягом 2013-2018 рр., до декриміналізації статті 205 Кримінального кодексу України (нагадаємо, кримінальні провадження за цією статтею декларувалися як один із інструментів боротьби із конвертаційними центрами і фріктивними поставками 3 метою незаконної податкової мінімізації), найбільшу вагу в структурі предикатних злочинів у кримінальних провадженнях, розпочатих правоохоронними органами за матеріалами Держфінмоніторингу, займали фріктивне підприємництво, привласнення, розтрата майна або заволодіння ним шляхом зловживання службовим становищем та шахрайство (рис. 2).

Аналізуючи структуру предикатних злочинів в обвинувальних вироках судів протягом останніх років, за результатами розгляду кримінальних проваджень, розпочатих та переданих до суду відповідними органами, можна виокремити основні види предикатних злочинів, які вчиняються 3 метою відмивання коштів, а саме: привласнення, розтрата майна або заволодіння ним шляхом зловживання службовим становищем; шахрайство, зокрема вчинене шляхом незаконних операцій з використанням ЕОМ; фріктивне підприємництво; зловживання владою або службовим становищем.

Аналізуючи результати досудового розслідування кримінальних правопорушень щодо вчинення предикатних злочинів, можна виокремити правопорушення 3 найбільшою часткою їх передачі до суду 3 обвинувальним актом в загальній кількості зареєстрованих, а саме: незаконні дії з документами на переказ - 76,9\%, привласнення, розтрата майна шляхом зловживання службовим становищем - 37,4\%, службове підроблення - 34,5\%, фріктивне підприємництво - 30,4\%, підроблення документів, печаток, штампів - 26,4\%, шахрайство 10,5\% [9]. Наведена інформація свідчить про низьку ефрективність досудового розслідування відповідними інституціями кримінальних правопорушень, пов'язаних із несплатою податків, що виявляється у високій частці закриття кримінальних правопорушень на етапі досудового розслідування та низькому рівні передачі інформації про кримінальні правопорушення з обвинувальним актом до суду.

За результатами розгляду судами протягом 2016-2018 рр. кримінальних проваджень щодо вчинених 14341 особою кримінальних правопорушень, які визначені в структурі основних предикатних злочинів, 10214 осіб (71\%) були засуджені. Най-

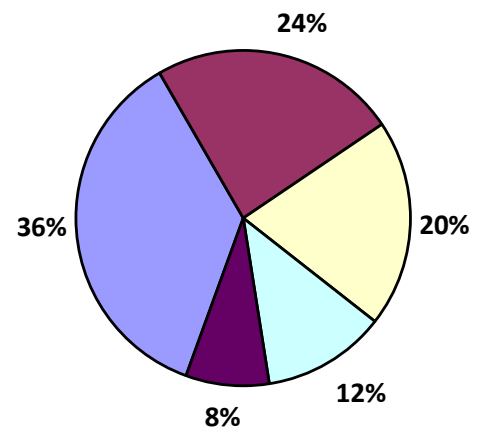

$\square$ Привласнення, розтрата майна або заволодіння ним шляхом зловживання службовим становищем

$\square$ Шахрайство, вчинене шляхом незаконних операцій 3 використанням ЕОМ

$\square$ зловживання владою або службовим становищем

$\square$ Фіктивне підприємництво

Інші

Рис. 2. Структура предикатних злочинів [9, с. 59-60]. 
більше осіб було засуджено за шахрайство - 5865 осіб або 57,4\%, підроблення документів, печаток, штампів - 2041 особа або 20,0\% та привласнення, розтрата майна шляхом зловживання службовим становищем - 1261 особа або 12,3\% [9]. Проте, слід зауважити, що за результатами розслідування лише одна із десяти справ, порушених на підставі, наприклад, ст. 212 КК України, передається до суду, а із тих, що розглядаються в судах, лише 9\% завершується вироками за даними Державної податкової служби та Генеральної прокуратури України [13]. Особливістю такого стану $є$ те, що стороні обвинувачення в цій категорії спорів складно довести умисел (суб'єктивна сторона складової злочину), що вимагає доопрацювання законодавства та завершення реформування відповідних інституцій

У 2019-2020 рр. у фріскальній та наближеній до неї сферах вже відбулися законодавчі зміни, а саме: відбулася вже згадувана декриміналізація фріктивного підприємництва, ухвалено Закон України “Про внесення змін до Кримінального кодексу та Кримінально-процесуального кодексу щодо зменшення тиску на бізнес" [14], а також законопроєкт № 1210 “Про внесення змін до Податкового кодексу України щодо вдосконалення адміністрування податків, усунення технічних та логічних неузгоденостей у податковому законодавстві" [15] тощо. Проте важливе питання щодо статусу органу досудового розслідування із підслідністю щодо злочинів у фріскальній сфрері так і не вирішено до сьогодні.

Щодо стану фрінансових злочинів у фріскальній сфері, то у 2019 р. було зареєстровано 1287 кримінальних проваджень за ухилення від сплати податків [13]. Такий показник на чверть менший (на 25,6\%) ніж кількість кримінальних проваджень, порівняно із 2018 р. Однак таке зменшення від- критих кримінальних проваджень радше є наслідком прийняття Закону України “Про внесення змін до Кримінального кодексу а Кримінально-процесуального кодексу щодо зменшення тиску на бізнес", а не дієвістю роботи відповідних органів.

Цікавою особливістю $є$ те, що у 2019 р. після перегляду кваліфікаційних порогів для притягнення до кримінальної відповідальності за ухилення від сплати податків 259 проваджень із 262 закриті за підстави відсутності складу/події кримінального порушення [13]. Загалом за останні три роки простежується стабільне зменшення кількості кримінальних проваджень, доведених до постановлення вироку і притягнення до відповідальності (рис. 3).

Така ситуація щодо стрімкого зниження кримінальних проваджень за ухилення від сплати податків, доведених до постановлення вироку і притягнення до відповідальності у 2017-2019 рр., свідчить не про зменшення таких злочинів, а про: фактичну безкарність вчинення злочинів у фіскальній сфері; бездіяльність або перевищення повноважень, тобто неналежне розслідування особами, що здійснюють розслідування цих злочинів, наявність корупційної складової у процесі досудового розслідування; некомпетентність (брак слідчих із фрінансовими знаннями) слідчих (детективів), що здійснюють розслідування злочинів у фіскальній сфрері, а також недостатній рівень знань у фіскальній сфері прокурорів, як процесуальних керівників таких слідчих.

До цього списку слід додати те, що найбільш складною частиною роботи податкових органів $є$ одержання інформації щодо правильності обчислення, повноти і своєчасності сплати до бюджетів, державних цільових фондів податків і зборів, обов'язкових платежів. Отримання такої інформації відбувається шляхом проведення перевірок, обстежень тощо. Науковці 

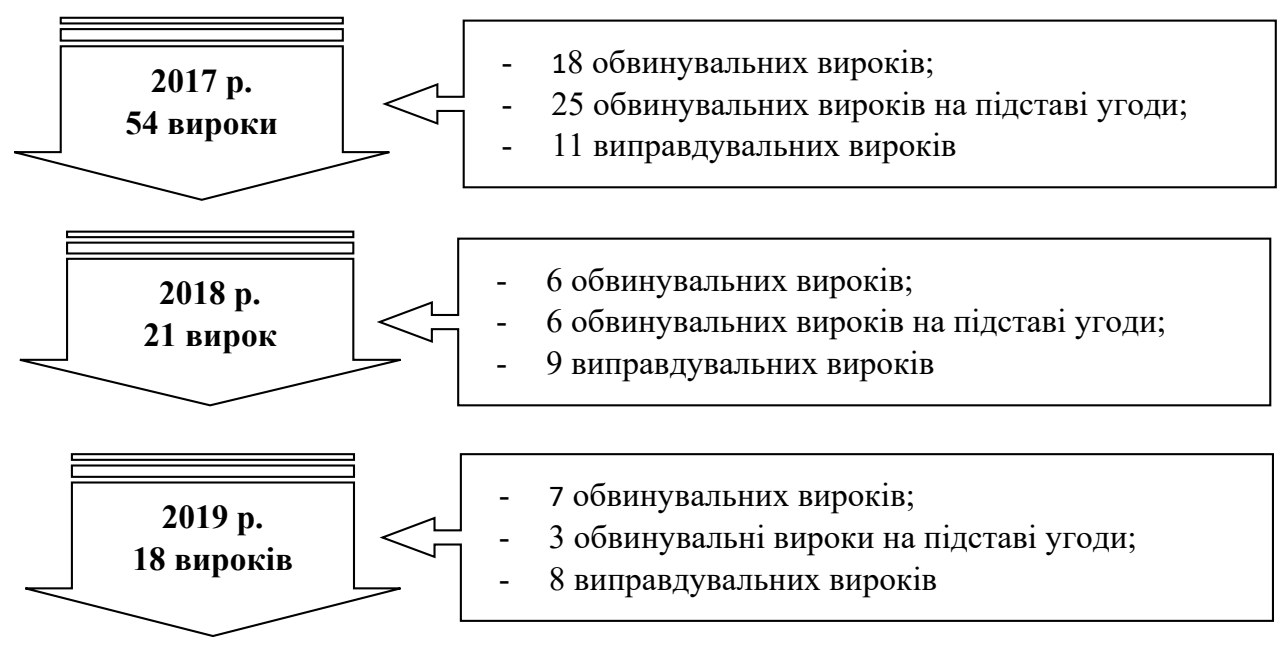

Рис. 3. Кількість кримінальних проваджень за ухилення від сплати податків, доведених до постановлення вироку і притягнення до відповідальності у 2017-2019 рр. [13]

поділяють їх на дві групи. Зокрема, вони стверджують, і з цим ми погоджуємося, що: “інформація про стан сплати податків надходить із різних джерел, враховуючи значення такої інформації, її обсяг та інші параметри. До першої групи відносять так звану власну інформацію системи органів Державної податкової служби. До другої інформацію, що надходить від платників податків і зборів (обов'язкових платежів), та інформацію, що надходить від підприємств, установ, організацій, які беруть участь у роботі зі справляння податків і зборів, обов'язкових платежів" [2, с. 9].

Щодо дієвості першої групи отримання інформації, то відповідно до п. 78.1 Податкового кодексу України [16] документальна позапланова перевірка здійснюється за наявності хоча б однієї з таких підстав: отримано рішення суду (слідчого судді) про призначення перевірки відповідно до пп. 78.1.11 п. 78.1 ст. 78 ПК України. А у редакції Кримінально-процесуального кодексу України [17], що була чинна до 15.07.2015 р., було пе- редбачено повноваження прокурора (п. 6 ч. 2 ст. 36 КПК України) та слідчого (п. 4 ч. 2 ст. 40 КПК України) призначати ревізії та перевірки у порядку, визначеному законом. Однак пп. 12 п. 5 розд. XII “Прикінцеві положення" Закону України "Про прокуратуру” [18], який набув чинності у липні 2015 р., вилучив із переліку повноважень прокурора та слідчого це право. Звідси, враховуючи відсутність прямої норми, яка б наділяла орган досудового розслідування та прокурора повноваженнями призначати податкову позапланову документальну перевірку або звертатися до слідчого судді із відповідним клопотанням у межах кримінального провадження, а слідчого суддю - розглядати такого роду клопотання, варто враховувати, що у разі призначення та проведення такої податкової перевірки в порядку пп. 78.1.11 п. 78.1 ст. 78 ПК України, висновки за результатом її проведення можна визнати незаконними в порядку адміністративного судочинства [19]. Тому належних правових підстав для проведення перевірок 
задля попередження, виявлення та боротьби із фінансовими злочинами у фіскальній сфері на сьогодні немає.

Висновки. Недостатньо чітко визначені функції існуючих інституцій, що здійснюють попередження, виявлення, розслідування фінансових злочинів у фіскальній сфері, породжують зростання недовіри громадян до держави. Для підвищення рівня захищеності економіки України від таких злочинів доцільним $€$ не лише створення єдиного органу 3 питань боротьби 3 фінансовою злочинністю, зокрема й у фіскальній сфері, а й систематичне оцінювання його діяльності. При цьому оцінювання діяльності такої інституції, як Бюро економічної безпеки, слід здійснювати за таким переліком критеріїв: рівнем громадської довіри; рівнем латентності фінансових злочинів у фіскальній сорері; профеесіоналізмом співробітників новоствореної установи та рівнем їх корумпованості; економічністю діяльності цієї інституції як суб'єкта забезпечення фінансово-економічної безпеки України.

Отже, створення єдиного органу як суб'єкта забезпечення економічної безпеки України з наданням широкого кола повноважень щодо попередження, виявлення й досудового розслідування економічних злочинів є необхідним і затребуваним.

\section{Список використаних джерел}

1. Про Бюро економічної безпеки України. Проект Закону України від 02.07.2020 № 3087-d. URL : http://w1.c1.rada.gov.ua/p/s/ zweb2/webproc4 1?pf3511=69331.

2. Цимбал П.В. Попередження, виявлення, розкриття та розслідування податкових злочинів : монографія. Ірпінь : Національний універcumem ДПС України, 2009. - 408 с.

3. Хоменко В.П. Запобігання злочинам у фріскальній сфрері як складова забезпечення фінансової безпеки держави. Науковий вісник
Національної академії внутрішніх справ. 2017. № 2(103). С. 37-45.

4. Фінансові розслідування у сфрері протидії легалізації злочинних доходів в Україні : метод. рек. Київ : Нац. акад. внутр. справ, 2017. 164 с.

5. Долбнєва Д. В. Особливості та результати проведення фрінансових розслідувань економічних злочинів на прикладі західного регіону. Бізнес інфоорм. 2019. № 3. С. 292-301.

6. Формування фоскального простору України в умовах глобалізаційних дисбалансів : монографрія / за ред. д.е.н., профр. А.І. Крисоватого. Тернопіль. 2018. С. 159-203.

7. Катамадзе Г. Про підслідність нового правоохоронного органу - Служби фінансових розслідувань. URL : https://biz.ligazakon.net/ analitycs/198133 grgol-katamadze-pro-pdsldnstnovogo-pravookhoronnogo-organu--sluzhbifnansovikh-rozslduvan.

8. Загальні тенденції тіньової економіки в Україні у січні-березні 2020 року. URL : https://www.me.gov.ua/Documents/List?lang=ukUA\&id=e384c5a7-6533-4ab6-b56f-50e5243eb15a \&tag=TendentsiiTinovoiEkonomiki.

9. Звіт про проведення національної оцінки ризиків у сфері запобігання та протидії легалізації (відмиванню) доходів, одержаних злочинним шляхом, та фрінансуванню тероризму. Національна оцінка ризиків проведена за координації Державної служби фінансового моніторингу України за підтримки Координатора проектів ОБСЄ в Україні. 2019. С. 250.

10. Кримінальний кодекс України. Закон України від 05.04.2001 № 2341-III. URL : $\underline{\text { https:// }}$ zakon.rada.gov.ua/laws/show/2341-14.

11. Про Державну фіскальну службу. Положення Кабінету міністрів України від 21 травня 2014 p. № 236. URL : https://zakon.rada.gov.ua/ laws/show/.

12. Захаров В.П. Легалізація (відмивання) доходів, одержаних злочинним шляхом: теоретико-правовий аспект. URL : http://science.Ipnu. ua /sites/default/files/journal-paper/2017/may/2171/ vnulpurn201480134.pdf. 
13. Статистика кримінальних проваджень з податків за 2019 рік. URL : http://kmp. ua/uk/analytics/infoletters/statistics-of-criminalproceedings-on-taxes-for-2019/.

14. Про внесення змін до Кримінального кодексу та Кримінально-процесуального кодексу щодо зменшення тиску на бізнес. Закон України від 18.09.2019 № 101-IX. URL : https://zakon.rada. gov.ua/laws/show/101-20\#Text.

15. Про внесення змін до Податкового кодексу України щодо вдосконалення адміністрування податків, усунення технічних та логічних неузгодженостей у податковому законодавстві. Закон України від 01.01.2021 № 466IX. URL : https://zakon.rada.gov.ua/laws/show/46620\#Text.

16. Податковий кодекс України. Закон України від 02.122010 № 2755-VI. URL : https:// zakon.rada.gov.ua/laws/show/2755-17\#Text.

17. Кримінально-процесуальний кодекс України. Закон України від 13.04.2012 № 4651-VI. URL : https://zakon.rada.gov.ua/laws/show/4651-17\#Text.

18. Про прокуратуру. Закон України від 14.10.2014 № 1697-VII. URL : https://zakon.rada. gov.ua/laws/show/1697-18\#Text.

19. Щеннікова Г. Позапланова податкова перевірка у рамках кримінального провадження: чи є шанс на оскарження? URL : https://biz. ligazakon.net/analitycs/191306 pozaplanovapodatkova-perevrka-u-ramkakh-krimnalnogoprovadzhennya-chi--shans-na-oskarzhennya.

\section{References}

1. Pro Biuro ekonomichnoi bezpeky Ukrainy. Proekt Zakonu Ukrainy vid 02.07.2020 № 3087-d [About the Bureau of Economic Security of Ukraine. Draft Law of Ukraine]. (2020, July, 2). Available at: http://w1.c1.rada.gov.ua/p/s/zweb2/ webproc4_1?pf3511=69331

2. Tsymbal, P. V. (2009). Poperedzhennia, vyiavlennia, rozkryttia ta rozsliduvannia podatkovykh zlochyniv [Prevention, detection, detection and investigation of tax crimes]. Irpin: Natsionalnyi universytet DPS Ukrainy [in Ukrainian].
3. Khomenko, V. P. (2017). Zapobihannia zlochynam u fiskalnii sferi yak skladova zabezpechennia finansovoi bezpeky derzhavy [Prevention of crimes in the fiscal sphere as a component of ensuring the financial security of the state]. Naukovyi visnyk Natsionalnoi akademii vnutrishnikh sprav Scientific Bulletin of the National Academy of Internal Affairs, 2 (103), 37-45 [in Ukrainian].

4. Finansovi rozsliduvannia u sferi protydii lehalizatsii zlochynnykh dokhodiv v Ukraini [Financial investigations in the field of combating money laundering in Ukraine]. (2017). Kyiv: Nats. akad. vnutr. [in Ukrainian].

5. Dolbnieva, D. V. (2019). Osoblyvosti ta rezultaty provedennia finansovykh rozsliduvan ekonomichnykh zlochyniv na prykladi zakhidnoho rehionu [Features and results of financial investigations of economic crimes on the example of the western region]. Biznes inform - Business inform, 3, 292-301 [in Ukrainian].

6. Krysovatyi, A. I. (Ed.). (2018). Formuvannia fiskalnoho prostoru Ukrainy v umovakh hlobalizatsiinykh dysbalansiv [The formation of the fiscal space of Ukraine in the context of globalization imbalances]. Ternopil [in Ukrainian].

7. Katamadze, H. Pro pidslidnist novoho pravookhoronnoho orhanu - Sluzhby finansovykh rozsliduvan [On the investigation of a new law enforcement agency - Financial Investigation Service]. Available at: https://biz.ligazakon.net/ analitycs/198133 grgol-katamadze-pro-pds/dnstnovogo-pravookhoronnogo-organu--sluzhbifnansovikh-rozslduvan.

8. Zahalni tendentsii tinovoi ekonomiky v Ukraini u sichni-berezni 2020 roku. [General trends of the shadow economy in Ukraine in JanuaryMarch 2020]. Available at: https://www.me.gov.ual Documents/List?lang=uk-UA\&id $=e 384 c 5 a 7-6533-$ 4ab6-b56f-50e5243eb15a\&tag=TendentsiiTinovoi Ekonomiki.

9. Zvit pro provedennia natsionalnoi otsinky ryzykiv u sferi zapobihannia ta protydii lehalizatsii (vidmyvanniu) dokhodiv, oderzhanykh zlochynnym shliakhom, ta finansuvanniu teroryzmu [Report on 


\section{ПОДАТКИ І ФІСКАЛЬНА ПОЛІТИКА}

the national risk assessment in the field of prevention and counteraction to legalization (laundering) of proceeds from crime and terrorist financing]. Natsionalna otsinka ryzykiv provedena za koordynatsii Derzhavnoi sluzhby finansovoho monitorynhu Ukrainy za pidtrymky Koordynatora proektiv OBSle $\checkmark$ Ukraini. The national risk assessment was coordinated by the State Financial Monitoring Service of Ukraine with the support of the OSCE Project Coordinator in Ukraine. (2019). [in Ukrainian].

10. Kryminalnyi kodeks Ukrainy. Zakon Ukrainy vid 05.04.2001 № 2341-III. [Criminal Code of Ukraine. Law of Ukraine]. (2001, April, 5). Available at: https://zakon.rada.gov.ua/laws/show/2341-14

11. Pro Derzhavnu fiskalnu sluzhbu. Polozhennia Kabinetu Ministriv Ukrainy vid 21.05.2014 r. № 236 [About the State Fiscal Service]. Regulations of the Cabinet of Ministers of Ukraine]. (2014, May, 21) Available at: https://zakon.rada.gov.ua/laws/show/.

12. Zakharov, V. P. Lehalizatsiia (vidmyvannia) dokhodiv, oderzhanykh zlochynnym shliakhom: teoretyko-pravovyi aspekt [Legalization (laundering) of proceeds from crime: theoretical and legal aspect]. Available at: http://science.Ipnu.ua /sites/ default/files/journal-paper/2017/may/2171/vnulpurn201480134.pdf.

13. Statystyka kryminalnykh provadzhen z podatkiv za 2019 rik [Statistics of criminal proceedings on taxes for 2019]. Available at: http://kmp.ua/uk/ analytics/infoletters/statistics-of-criminal-proceedings-on-taxes-for-2019/

14. Pro vnesennia zmin do Kryminalnoho kodeksu ta Kryminalno-protsesualnoho kodeksu shchodo zmenshennia tysku na biznes. Zakon Ukrainy vid 18.09.2019 № 101-IX [On amendments to the Criminal Code and the Code of Criminal Procedure to reduce the pressure on business. Law of Ukraine]. (2019, September, 18). Available at: https://zakon.rada.gov.ua/laws/show/101-20\#Text
15. Pro vnesennia zmin do Podatkovoho kodeksu Ukrainy shchodo vdoskonalennia administruvannia podatkiv, usunennia tekhnichnykh ta lohichnykh neuzghodzhenostei u podatkovomu zakonodavstvi. Zakon Ukrainy vid 01.01.2021 № 466-IX [On amendments to the Tax Code of Ukraine to improve tax administration, eliminate technical and logical inconsistencies in tax legislation. Law of Ukraine]. (2021, January, 1). Available at: https:// zakon.rada.gov.ua/laws/show/466-20\#Text.

16. Podatkovyi kodeks Ukrainy. Zakon Ukrainy vid 02.122010 № 2755-VI [Tax Code of Ukraine. Law of Ukraine]. (2021, January, 1). Available at: $\quad$ https://zakon.rada.gov.ua/laws/show/275517\#Text.

17. Kryminalno-protsesualnyi kodeks Ukrainy. Zakon Ukrainy vid 13.04.2012 № 4651-VI [Criminal Procedure Code of Ukraine. Law of Ukraine]. (2021, January 14). Available at: https://zakon. rada.gov.ua/laws/show/4651-17\#Text

18. Pro prokuraturu. Zakonu Ukrainy vid 14.10.2014 № 1697-VII. [About the prosecutor's office. Law of Ukraine]. (2014, October, 14). Available at: https://zakon.rada.gov.ua/laws/show/169718\#Text.

19. Shchennikova, H. Pozaplanova podatkova perevirka u ramkakh kryminalnoho provadzhennia: chy ye shans na oskarzhennia? [Unscheduled tax audit in criminal proceedings: is there a chance to appeal?]. Available at: https://biz.ligazakon.net/ analitycs/191306 pozaplanova-podatkova-perevrka-u-ramkakh-krimnalnogo-provadzhennya-chi-shans-na-oskarzhennya

Стаття надійшла до редакції 16.12.2020. 